\title{
The Classical Gold Standard: Some Lessons for Today
}

\author{
MICHAEL DAVID BORDO
}

HE widespread dissatisfaction with almost two decades of worldwide inflation has prompted interest in a return to some form of a gold standard. ${ }^{1}$ Some crucial questions must be answered, however, before such interest can be taken seriously. Two questions immediately come to mind: How did the actual gold standard operate? What was its record for providing stable prices and overall economic stability?

This article attempts to answer these two questions. It focuses primarily on what is commonly referred to as the "Classical Gold Standard," which prevailed in its most pristine form between 1880 and 1914."

The first section discusses some fundamentals of the gold standard. This is followed by a discussion of the "Managed Gold Standard" which characterized much of the pre-World War I period. Following that is a brief narration of the history of the gold standard. Next, some empirical evidence is presented on the performance of the economies of the United States and the United Kingdom under the gold standard. Finally, the case for a return to the gold standard is examined.

The evidence presented in this article suggests that, in several respects, economic performance in the United States and the United Kingdom was superior under the classical gold standard to that of the subsequent period of managed fiduciary money. ${ }^{3}$ In partic-

The author, professor of economics at the Unimersity of South Carolina, Columbia, is a Visiting Scholar at the Federal Reserve Bank of St. Louis.

1. Endeed, the recently appointed federal Gold Commission has been established to consider the case for a greater role for gold in the U.S. monetary system. For a recent discourse on the case for a return by the United States to some form of the gold standard, see Robert M. Bleiberg and James Grant, "For Real Money: The Dollar Should be as Good as Gold," editorial commentary, Barron's, June 15, 1981.

2However, aspects of the gold standard persisted in various foms until the 1971 breakdown of the Bretton Woods System.

3"Managed fiduciary money" means a monetary standard ander which the government is not committed to maintain a fixed price of gold. The United States had such a standard from 1861 ular, both the price level and real economic activity were more stable in the pre-World War I gold standard era than in the subsequent six-and-one-half decades. Much of the relatively poor performance of the post-World War I period, however, occurred in the interwar period, a period characterized by deflation, real output instability and high unemployment.

\section{WHAT WAS THE GOLD STANDARD?}

The gold standard essentially was a commitment by participating countries to fix the prices of their domestic currencies in terms of a specified amount of gold. The countries maintained these fixed prices by being willing to buy or sell gold to anyone at that price. Thus, for example, from 1821 to 1914, Great Britain maintained a fixed price of gold at $23,17 \mathrm{~s}, 101 / 2 \mathrm{~d}$; the United States, over the $1834-1933$ period, maintained the price of gold at $\$ 20.67$ per ounce (with the exception of the Greenback era from 1861 to 1878 ).

\section{Why Gold?}

Gold has the desirable properties of money that early writers in economics have stressed. It is durable, easily recognizable, storable, portable, divisible and easily standardized. Especially important, changes in its stock are limited, at least in the short run, by high costs of production, making it costly for governments

to 1878 , and has been on one since 1971 . Under such a standard, nonetary authorities have complete control over the domestic money supply. An alternative situation, often characterized as "managed" money, occurs when monetary authorities, though committed to maintaining a fixed price of gold, engage in a systematic policy of sterilizing (or neutralizing) the influence of gold flows on the domestic money supply by using offsetting open market operations. Although the United States was still on the gold standard, the period from 1914 to 1933 in U.S. monetary history can thus be viewed as a period of "managed" money because of the freqnent sterilizing activity of the Federal Reserve System. See Milton Friedman and Anna Jacobson Schwartz, A Monetary History of the United States 1867-1960 (Princeton University Press, 1963). 
to manipulate. ${ }^{4}$ Because of these physical attributes, it emerged as one of the earliest forms of money.

More important, gold was a commodity money, and a commodity money standard, regardless of the commodity involved, has a very desirable property: it ensures through the operation of the competitive market a tendency toward long-run price stability. ${ }^{5}$ Under a commodity money standard, the purchasing power of a unit of commodity money, or what it will buy in terms of all other goods and services, will always tend toward equality with its long-rum cost of production.

\section{The Gold Standard and a Closed Economy}

Consider first the example of a closed economy one that does not trade with any other country - that produces gold and uses only gold coins as money, In this country, the govermment is commited to purchase gold from the public on demand at a fixed price and to convert it into gold coin. Similarly, the government will sell gold to the public at the fixed price. ${ }^{6}$ The price level (the average of the prices of all goods and services produced in the country) will be determined by the equality of the quantity of gold coins demanded and supplied.

The supply of gold coins is determined by the supply of gold in the economy and by the amount of gold used for nonmonetary purposes. The supply of gold in the long run is determined by the opportunity cost of producing gold - the cost in terms of foregone labor, capital and other factors engaged in producing an ad. ditional unit of gold. The fraction of gold devoted to nonmonetary uses is determined by the purchasing power of gold in terms of all other commodities. The demand for gold coins is determined by the community's wealth, tastes and the opportunity cost of holding money relative to other assets (the interest rate).

In the long run, competition in the gold-producing industry ensures that the purchasing power of gold money in terms of all other goods will equal the oppor-

\footnotetext{
4 Of course, in earlior times, governments have manipulated gold by debasement, clipping, etc. Such practices, however, were the exception. See Anna J. Schwartz, "Secular Price Change in Historical Perspective," Jotumal of Monay, Credit and Banking (February 1973, Part 2), pp. 243-69.

5 For a lucid discussion of the theory of commodity money see Miton Friedman, "Commodity-Reserve Currency" in Miltom Friedman, Essays in Postive Economics (University of Chicago Press, 1953).

IIn actuality the buying and selling prices will differ, reflecting the cost of certifying and minting coins. This difference is
} referred to as brassage. tunity cost of producing an additional unit of gold money.

To see how this works, consider what happens when a technological advance improves productivity in the non-gold-producing sectors of the economy. This improvement leads to a rise in real economic activity, an increase in the demand for money (gold coins) and, with an initially given stock of money, a fall in the price level (a rise in the purchasing power of gold money). The fall in the price level means that gold producers will be eaming economic profits. These profits will encourage existing owners to increase production and new entrepreneurs to enter the industry, resulting in an increase in gold production. ${ }^{7}$ At the same time, people will take gold previously used for nonmonetary purposes and convert it to monetary uses (e.g, they will sell gold jewelry to the government and have it coined). These forces will increase the gold coin supply, reversing the initial decline in the price level. ${ }^{8}$

In a similar manner, increases in the price level, caused, for example, by a gold discovery which increases the stock of gold and the supply of gold coins, will, by reducing the purchasing power of gold money, cause the community to shift gold from monetary to nonmonetary uses, and will eventually reduce production in the gold producing industries. Both factors will tend to reduce the gold money supply and reverse the initial rise in the price level. Thus, under a gold standard, one would expect to observe long-run price level stability, though it may take several years for a declining or rising price level to be reversed. ${ }^{9}$

\section{The Gold Standard and Open Economies}

If, instead of a closed economy, we have a world in which a number of countries are on a gold coin

\footnotetext{
TIn addition, exploration for new sources of gold and attempts to more efficiently mine existing sources will result.

8 Also, rising prices will be accompanied by rising wages and other costs, making gold mining a less profitable activity, "Thi analysis assumes constant costs; with inereasing costs the purchasing power of gold will be higher and the price level lower.

9his analysis is static. In a dynamic context, growing real output will produce a tendency towards secular deflation unless gold output expands at the same rate as real economic activity, This will happen if the rate of technological advance is the same in the gold-producing sectors of the economy as in the rest of the econony or if the opening of new nines proceeds apace with real growth. In a world characterized by purely stochastic events such as major gold discoveries, the price level will diverge from its long-run trend for a very long time, giving the appearance of long-run price instability. However, to the extent that gold discoveries are not random events but occur in response to rises in the purchasing power of gold, these extended periods of inflation and deflation are part of the equlibrating process of a commodity standard.
} 
standard, a mechanism is introduced that ensures uniform price movements across these countries.

Consider, for example, two countries that were on the gold standard, the United States and the United Kingdom. As mentioned above, each country fixed the price of its currency in terms of gold - the United States fixed the price of one ounce of gold at $\$ 20.67$. while the United Kingdom set it at $23,17 \mathrm{~s}, 101 / 2 \mathrm{~d}$. Thus, the dollar/pound exchange rate was perfectly determined. The fixed exchange rate of $\$ 4.867$ per pound was referred to as the par exchange rate. ${ }^{10}$

Under the gold standard fixed exchange rate system, disturbances in the price level in one country would be wholly or in part offset by an automatic balance-of-payments adjustment mechanism called the price-specie-flow mechanism. Consider again the example where a technical advance in the United States lowers the U.S. price level. The fall in U.S. prices will result in lower prices of U.S. exports, which will decline relative to the prices of imports, determined largely by prices in the rest of the world. This change in terms of trade (the ratio of export prices to import prices) will cause foreigners to demand more U.S. exports, and U.S. residents to demand fewer imports. A U.S. balance-of-payments surplus will be created, causing gold to flow into the United States from the United Kingdom. ${ }^{11}$ The gold inflow will increase the U.S. money supply, reversing the initial fall in prices. At the same time, in the United Kingdom, the gold outflow will reduce the U.K. money supply, thus re ducing its price level. In final equilibrium, price levels in both countries will be somewhat lower than they were prior to the technical advance in the United States. Thus, the operation of the price-specie-flow mechanism served to keep prices in line across the world. ${ }^{12}$

10The U.K. definition of an ounce of gold was $11 / 12$ of the U.S. definition. Actually, under the gold standard, the exchange rate was never exactly fixed. It varied within a range bounded by the gold points - the costs of transporting gold between the United States and the United Kingdom. Thus, if Americans reduced their demand for British gooks and hence for pounds to pay for them, the dollat price of the pound would decline. When the dollar price of the pound declined to, say, $\$ 4.80$, it wowld pay to melt down English gold sovereigns into bullion, ship the bullon to the Unitet States and eonvert it into U.S. goll coins.

${ }^{11}$ In this simple example, the increased British demand for U.S. goods lowers the pound to the gold export point. As a consequence, British importers convert pounds into bullion and ship them to the United States, converting them wo U.S. gold dollars to pay for the American goods.

${ }^{12}$ An alternative to the balance-of-payments adjustment mechanism described above is called the Monetary Approach to the Balance of Payments. See Hary $G$. Johnson, "The Monetary Approach to Balance of Payments Theory" in Jacob $A$ Frenkel and Harry G. Johnson, eds., The Monetary Approach to the Balance of Payments (Alen and Unwin, 1976). Ac-
In sum, the gold standard as a commodity money standard provided a mechanism to ensure long-rum price level stability both for individual countries and groups of countries. Each country had only to maintain a fixed price of gold.

\section{THE MANAGED GOLD STANDARD}

The simple model of the gold standard just described was seldom followed in practice. The pure gold coin standard had two features that caused most countries to modify its operation: (1) very high resource costs were required to maintain a full commodity money standard and (2) strict adherence to the "iron discipline" of the gold standard required each country to subsume its internal balance (domestic price and real output stability) to its external balance (balance-of-payments equilibrium). Thus, if a country was ruming a balance-of-payments deficit, the "rules of the game" required it to deflate the economy until "purchasing power parity" was restored at the par exchange rate. ${ }^{13}$ Such deflation leads to a reduction in real output and employment. Consequently, a meaningful discussion of how the gold standard actually operated before World War I requires a discussion of the ways in which nations modified the gold standard to economize on gold and to shield domestic economic activity from external disturbances.

\section{The Use of Fiduciary Money}

As mentioned above, high resource costs are required to maintain a full commodity money standard. Discovering, mining and minting gold are costly activities. ${ }^{14}$ Consequently, as nations developed, they evolved substitutes for pure commodity money. These substitutes encompassed both govermment-provided paper money (referred to as fiat money) and privately

cording to this approach, through the process of arbitrage the buying and selling of similar commodities in different markets - the prices of all internationally traded goods, exports, imports and close substitutes, will be the same around the world expressed in similar currency units. Moreover, the prices of domestic goods and services (non-traded goods) will be kept in line with prices of internationaly traded goods by domestic arbitrage. Hence, instead of U.S. prices falling first in response to an excess demand for money, and the terms of trade subsecuently changing, the excess demand for money will be satisfied directly by the import of gold (through a balance-of payments surplus) with no change in the terms of trade.

13Purchasing power parity is the ratio of the domestic country's price level (valtue of money) to that of its principal trading partuers.

14 Fiednan estimated the cost of maintaining a fall gold coin standard for the United States in 1960 to be more than $21 / 2$ percent of CNP. See Milton Friedman, A Program for Monetary Stability (Fordham University Press, 1959). 
produced fiduciary money (bank notes and bank deposits). As long as governments maintained a fixed ratio of their notes to gold, and commercial banks kept a fixed ratio of their liabilities to gold (or to government notes and gold), a gold standard could still be sustained. This type of standard prevailed throughout the world before World War I.

One aspect of this "mixed" gold standard system was that one unit of a country's gold reserves could support a multiple number of units of domestic money (e.g., the U.S. ratio of money to the monetary gold stock was 8.5 in the $1880-1913$ period). This meant that in the short run gold flows had powerful effects on the domestic money supply, spending and prices. ${ }^{15}$

\section{Intenational Capital Flows}

So far, the discussion abstracts from the role of capital flows between countries. In the pre-World War I gold standard era, most international trade was financed by credit, the issuing of short-term claims in the London money market. ${ }^{16}$ In addition, economic projects in the less-developed economies were generally financed by long-term loans from investors in England, France and other advanced countries. ${ }^{17}$ The influence of these capital flows significantly reduced the burden of gold flows in the adjustment mechanism.

Consider the example of a gold discovery in a particular country. The discovery would lead to a rise in the domestic money supply, which both raises domestic price levels and reduces domestic interest rates in the short run. ${ }^{18}$ The reduction in domestic interest rates relative to interest rates in other countries would induce investors to shift their funds to foreign money markets. This produces a gold outflow, thereby reducing the amount of adjustment required through changes in the terms of trade. Also, to the extent that short-term capital serves as a substitute for gold as an international reserve asset, and domestic financial intermediaries hold balances with correspondents

\footnotetext{
1 İI also meant that changes in the composition of the money supply between high-powered money (gold coins and government paper) and bank-provided money (notes and depasits) could be a source of monetary instability.

16See Arthur I. Bloomfield, Short-Term Capital Movements Under the Pre-1914 Gold Standard, Princeton Studies in International Finance No. I. (Princeton University, 1963).

17 See Arthur I. Bloomfield, Patterns of Fluctuation in Internafional Investment before 1914, Princeton Studies in Intemational Finance No. 21. (Princeton University, 1968).

${ }^{18}$ This is the so-called liquidity effect. To induce the community to hold a larger fraction of its wealth in the form of money rather than interest-bearing securities, the price of securities must rise (the interest rate must fall).
}

abroad, smaller gold flows would be required to settle international payments imbalances.

Finally, consider the role of long-term capital movements. In the pre-World War I era, the real rate of return on capital was higher in developing countries such as the United States, Canada and Australia than in European countries such as the United Kingdom and France. As a consequence, British investors, for example, invested heavily in American industries and utilities by purchasing long-term securities. The demand by British investors for American securities (other things equal) created an excess demand for dollars at the par exchange rate (or equivalently an excess supply of pounds). The resulting gold inflow into the United States raised the U.S. money supply, leading to a rise in the U.S. price level. The resultant rise in export prices relative to import prices led to an increased demand by U.S. residents for imports (primarily manufactured goods from the United Kingdom). Thus, the transfer of capital resulted in a transfer of real resources from the United Kingdom to the United States. Indeed, in the pre-World War I era, it was normal for a developing country such as the United States to run a persistent balance-of-payments deficit on current account (imports of goods and services exceeding exports of goods and services), financed primarily by long-term capital inflows.

\section{The Role of Central Banks in the Gold Standard}

Under a strict gold standard, there is no need for a central bank. What is required is a governmental authority to maintain the fixed domestic currency price of gold by buying and selling gold freely. ${ }^{19}$ Indeed, many countries on the gold standard prior to World War I (e.g., the United States and Canada) did not have central banks. Most European countries, on the other hand, have had central banks that predated the gold standard. These institutions, in most cases, had evolved from large commercial banks that served as bankers to the government (e.g., the Bank of England, founded in 1697) into institutions serving as lenders of last resort to the banking community.

Under the classical gold standard, central banks were supposed to follow the rules of the game - to speed up the adjustment of the domestic money supply and price level to external gold flows. The classical model of central bank behavior was the Bank of England, which played by the rules over much of the

\footnotetext{
${ }^{19}$ However, a substantial gold reserve is required to do this effectively.
} 
1870-1914 period. ${ }^{20}$ Whenever Great Britain faced a balance-of-payments deficit and the Bank of England saw its gold reserves declining, it raised "bank rate," the rate of interest at which it was willing to discount money market paper. By causing other interest rates to rise, the rise in bank rate was supposed to produce a reduction in holdings of inventories and a curtailment of other investment expenditures. The reduction in investment expenditures would then lead to a reduction in overall domestic spending and a fall in the price level. At the same time, the rise in bank rate would stem any short-term capital outflow and attract short-term funds from abroad.

For most other countries on the gold standard, there is evidence that interest rates were never allowed to rise enough to contract the domestic price level that these countries did not follow the rules of the game. ${ }^{21}$ Also, many countries frequently followed policies of sterilizing gold flows - attempting to neutralize the effects of gold flows on the domestic money supply by open market purchases or sales of domestic securities. ${ }^{22}$

\section{Reserve Currencies and the Role of Sterling}

An important addition to the gold standard story is the role of key currencies. ${ }^{29}$ Many countries under the pre-World War I gold standard held their international reserves in gold and in the currencies of several major countries. The center of the international payments mechanism was England, with the Bank of England maintaining its international reserves primarily in gold. Most other countries kept reserves in the form of gold and sterling assets. Between 1900

20However, most other central banks apparently did not. See Arthur I. Bloomfield, Manetary Policy under the International Gotd Standard: 1880-1914 (Federal Reserve Bank of New York, 1959).

21 Noted examples are France and Belgium. See P. B. Whale, "The Working of the Pre-War Gold Standard," Economica (February 1937), pp. 18-32, and Bloomfield, Monetary Policy under the International Gold Standard.

22Usually, gold outflows were offset by open market purchases of domestic securities. For the U.S. experience, see Friedman and Schwartx, A Monetary History of the United States. For other countries see Bloomfield Monefary Policy under the International Gold Standard. Such behavior could not persist, however, if a country wished to maintain its link with gold, becanse if the disequilibrium producing the gold flow were permanent (e.g., the domestic price level were higher than world prices), then gold outflows would continue until all of the country"s gold reserves were exhausted. (In the case of an inflow, it would continue antil the monetary base consisted entirely of gold.)

${ }^{23}$ Much of this discussion derives from Peter H. Lindert Key Currencies and Gold, 1900-1913, Princeton Studies in International Finance No. 24 (Princeton University, 1969). and 1914, two other major European capitals also served as reserve centers - Paris and Berlin, each of which held reserves in gold, sterling and the other country's currency. Finally, a number of smaller European countries held reserves in the form of francs and marks.

In addition, an elaborate network of short-term financial arrangements developed between private financial institutions centered in the London money market. This network of reserve currencies and shortterm international finance had two important results. First, England (the Bank of England) could act as an umpire (or manager) of the world gold standard system without having to hold excessive gold reserves. ${ }^{24}$ By altering its bank rate, the Bank of England caused repercussions around the world. ${ }^{25}$

Second, much of the balance-of-payments adjustment mechanism in the pre-World War I period did not require actual gold flows. Instead, the adjustment consisted primarily of transfers of sterling and other currency balances in the London, Paris, Berlin and New York money markets. ${ }^{26}$ In addition, short-term capital flows accommodated the balance-of-payments adjustment mechanism in this period. ${ }^{27}$ Indeed, the pre-World War I gold standard has often been described as a sterling standard. ${ }^{28}$

In sum, the gold standard that emerged before World War I was very different from the pure gold coin standard outlined earlier. Unlike the pure gold coin standard, countries economized on the use of gold both in their domestic money supplies and as a means of settling international payments imbalances. In addition, to avoid the iron discipline of the gold standard, central banks in some countries did not follow the rules of the game, and some countries even

24Indeed, England's total gold reserves in 1913 only accounted for 9.5 percent of the world's monetary gold stock while the Bank of England's holdings accounted for 3.6 percent. See John Maynard Keynes, A Treatise on Money: 2, The Applied Theory of Money in Elizabeth Johnson and Donald Moggridge, eds., The Collected Writings of John Maynard Keynes, vol. VI (Macmillan, 1971).

25It likely caused monetary crises in the United States in the 1838-43 period and 1873. See Peter Temin, The Jacksonian Economy (W. W. Norton, 1969) and Friedman and Schwartz, A Monetary History of the United States.

${ }^{20}$ Also in the period after 1900 , instead of gold actually being transported betweer centers, the practice of "earmarking" gold holdings in mator centers gained importance.

2:See Bloomfield, Short-Term Capital Movements.

28See Melchior Palyi, The Tuilight of Gold, 1914 to 1936: Myths and Realities (Henry Regnery Co, 1972) and David Williams, "The Evolution of the Sterling System" in C. R. Whittlesey and J. S. G. Wilson, eds., Essays in Money and Banking in Honour of R. S. Sayers (Clarendon Press, 1968). 
abandoned the gold standard periodically, ${ }^{29}$ The final modification to the pure gold standard was the key role played by the Bank of England as umpire to the system. The result was a "managed gold standard," not the pure gold coin standard often extolled as the best example of a commodity money system.

\section{CHHONOLOGY OR THE GOLD}

\section{STANDATD: 1821-1971}

This section briefly sketches the chronology of the gold standard from the end of the Napoleonic Wars to the collapse of Bretton Woods.

\section{The Classical Gold Standard: 1821-1914}

In the 18th century, England and most other countries were on a bimetallic standard based primarily on silver. ${ }^{30}$ When Great Britain restored specie payments in 1821 after the Napoleonic War inflation episode, the gold standard was restored. From 1821 to 1880 , the gold standard steadily expanded as more and more countries ceased using silver. ${ }^{31}$ By 1880 , the majority of countries in the world were on some form of a gold standard.

The period from 1880 to 1914 , known as the heyday of the gold standard, was a remarkable period in world economic history. It was characterized by rapid economic growth, the free flow of labor and capital across political borders, virtually free trade and, in general, world peace. These external conditions, coupled with the elaborate financial network centered in London and the role of the Bank of England as umpire to the system, are believed to be the sine qua non of the effective operation of the gold standard ${ }^{32}$

\footnotetext{
29 Argentina and other Latin American countries, for example. See Alec George Ford, The Gold Standard, 1880-1914, Britain and Argentina (Clarendon Press, 1962).

:oUnder a bimetallic standard, each of two precious metals, gold and silver, serves as legal tender, and the two metals are kept by the mint in a fixed proportion to each other. The relationship between the official exchange rate of gold for silver and the market rate will determine whether either one or both metals is used as money. For example in 1834, the United States raised the nint ratio of silver to gold from $15: 1$ to $16: 1$, hence valuing silver slightly lower relative to gold than the world inarket. As a result, little silver was offered for coinage and the United States was in effect on the gold standard. See Leland B. Yeager, International Monetary Relations; Theory, Fistory and Policy, 2nd ed. (Harper and Row, 1976), p. 296.

81The switch from silver to gold reflected both changes in the relative supplies of the two precious metals resulting from the gold discoveries of the $1840 \mathrm{~s}$ and ${ }^{7} 50 \mathrm{~s}$ and a growing preference for the more precious metal as world real income rose.

32See Palyi, The Twilight of Gold and Yeager, International Monetary Relations.
}

\section{The Gold Exchange Standard: 1925-31}

The gold standard broke down during World War $\mathrm{I}, 33$ was succeeded by a period of "managed fiduciary money," and was briefly reinstated from 1925 to 1931 as the Gold Exchange Standard. Under the Gold Exchange Standard, countries could hold both gold and dollars or pounds as reserves, except for the United States and the United Kingdom, which held reserves only in gold. In addition, most countries engaged in active sterilization policies to protect their domestic money supplies from gold Hows.

The Gold Exchange Standard broke down in 1931 following Britain's departure from gold in the face of massive gold and capital flows and was again succeeded by managed fiduciary money.

\section{The Iretton Woods Syatem: 1946-71}

The Bretton Woods System was an attempt to return to a modified gold standard using the U.S. dollar as the world's key reserve currency. All other countries - except for the sterling bloc-settled their international balances in dollars. The United States fixed the price of gold at $\$ 35.00$ per ounce, maintained substantial gold reserves, and settled external accounts with gold bullion payments and receipts.

In the post-World War II period, persistent U.S. balance-of-payments deficits helped finance the recovery of world trade from the aftermath of depres. sion and war. However, the steady growth in the use of U.S. dollars as international reserves and persistent U.S. deficits steadily reduced U.S. gold reserves and the gold reserve ratio, reducing public confidence in the ultimate ability of the United States to redeem its currency in gold. ${ }^{34}$ This "confidence problem" coupled with many nations' aversion to paying both seigniorage and an "inflation tax" to the United States in the post1965 period, led to the ultimate breakdown of the Bretton Woods system in $1971 .^{35}$ The U.S. decision in 1971 to abandon pegging the price of gold was the final demise of the gold standard.

\footnotetext{
3aThe United States alone remained on the gold standard, except for a brief embargo on gold exports from 1917 to 1919 .

${ }^{34}$ See H. G. Johnson, "Theoretical Problems of the International Monetary System," in R. N. Cooper, ed., International Finance (Penguin Books, 1971), pp. 304-34.

35 Seigniorage here refers to the retum earned by the U.S. monetary authotities on the issue of outstanding paper money liabilities. It is measured by the interest foregone by foreign holders of U.S. money balances. The "inflation tax" refers to the depreciation in real purchasing power of outstanding money balances.
} 


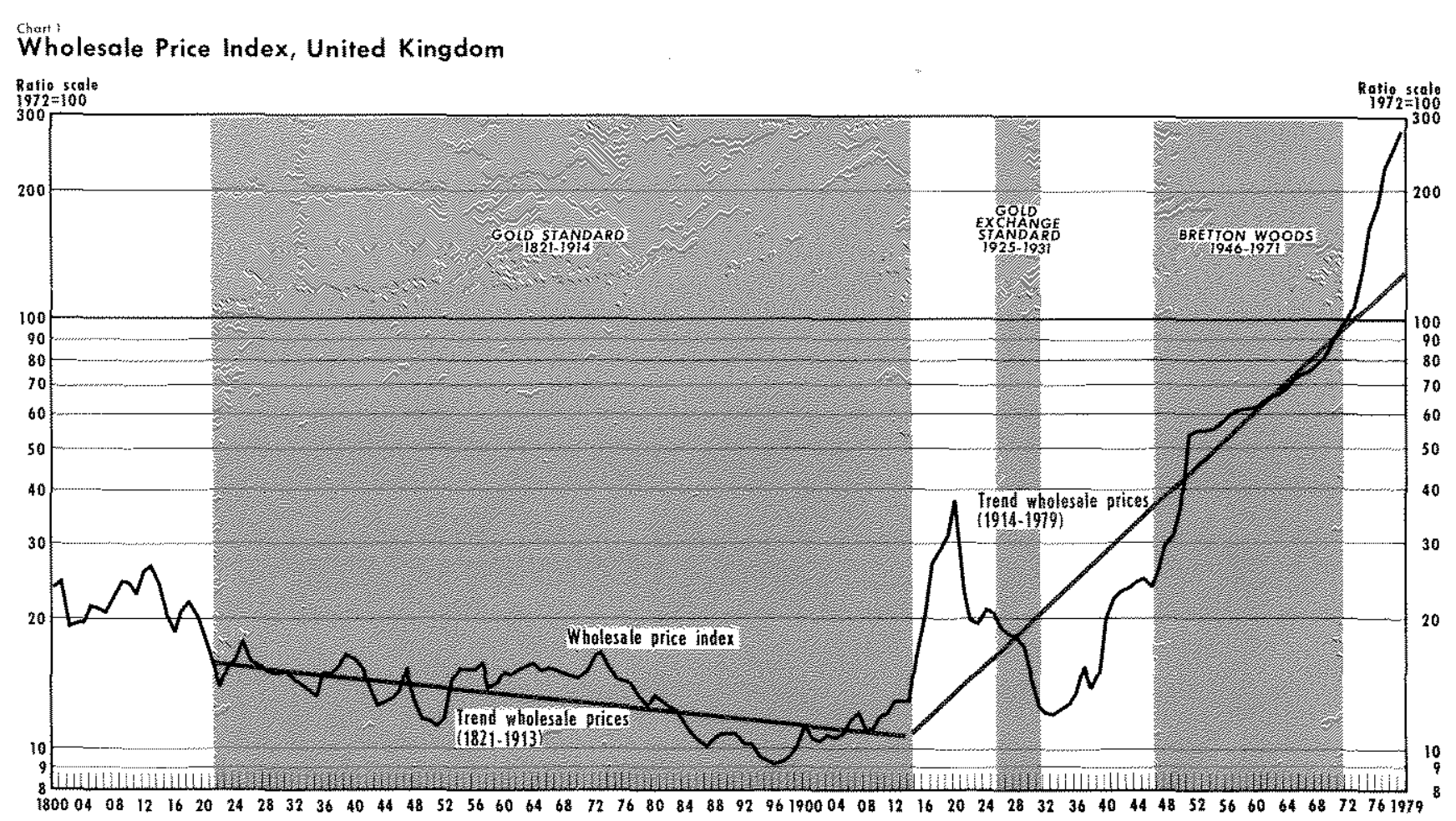

\section{THE RECORD OF THE GOLD STANDARD}

This section briefly examines the stability of the price level and real output for the United Kingdom and the United States under both the gold and managed fiduciary money standards. Charts 1 and 2 portray the behavior of the wholesale price index from 1800 to 1979 for both countries.

From 1797 to 1821 , during and immediately following the Napoleonic Wars, the United Kingdom was on a fiat (or paper) standard; it officially joined the gold standard in 1821, maintaining a fixed price of gold until 1914. There is little change in the U.K. price level comparing the first year of the gold standard, 1821, to the last, but over the whole period there was a slight downward trend in prices, declining on average by 0.4 percent per year. Within that approximate 100 year span, however, periods of declining prices alternated with periods of rising prices, a pattern consistent with the commodity theory of money. Prices fell until the mid-1840s, reflecting the pressure of rising real incomes on the limited stock of gold. Following the Califormia and Australian gold discoveries of the late 1840 s and early $1850 \mathrm{~s}$, prices turned around and kept rising until the late 1860s. This was followed by a 25-year period of declining prices, again reflecting both rising real income and expansion of the number of countries on the gold standard. This deflation ended after technical advances in gold processing and major gold discoveries in the late $1880 \mathrm{~s}$ and $1890 \mathrm{~s}$ increased world gold supplies.

The United States followed a pattern similar to the United Kingdom, experiencing a slight downward trend in the price level with prices declining on average by 0.14 percent per year from 1834-1913. The country adopted the gold standard in 1834 (it had been on silver for the preceding 35 years) and remained on it at the same price of gold until World War I, with the exception of the Greenback episode from 1861 to $1878 .^{38}$ During that period, the country abandoned the gold standard and prices increased rapidly until 1866 . To restore convertibility to gold, prices had to fall sufficiently to restore the pre-war purchasing power parity. This occurred in the rapid deflation from 1869 to 1879 .

The period since World War I has not been charac-

36 Also to be excluded from the gold standard are the turbulent years 1838-1843, during which specie payments were generally suspended. 


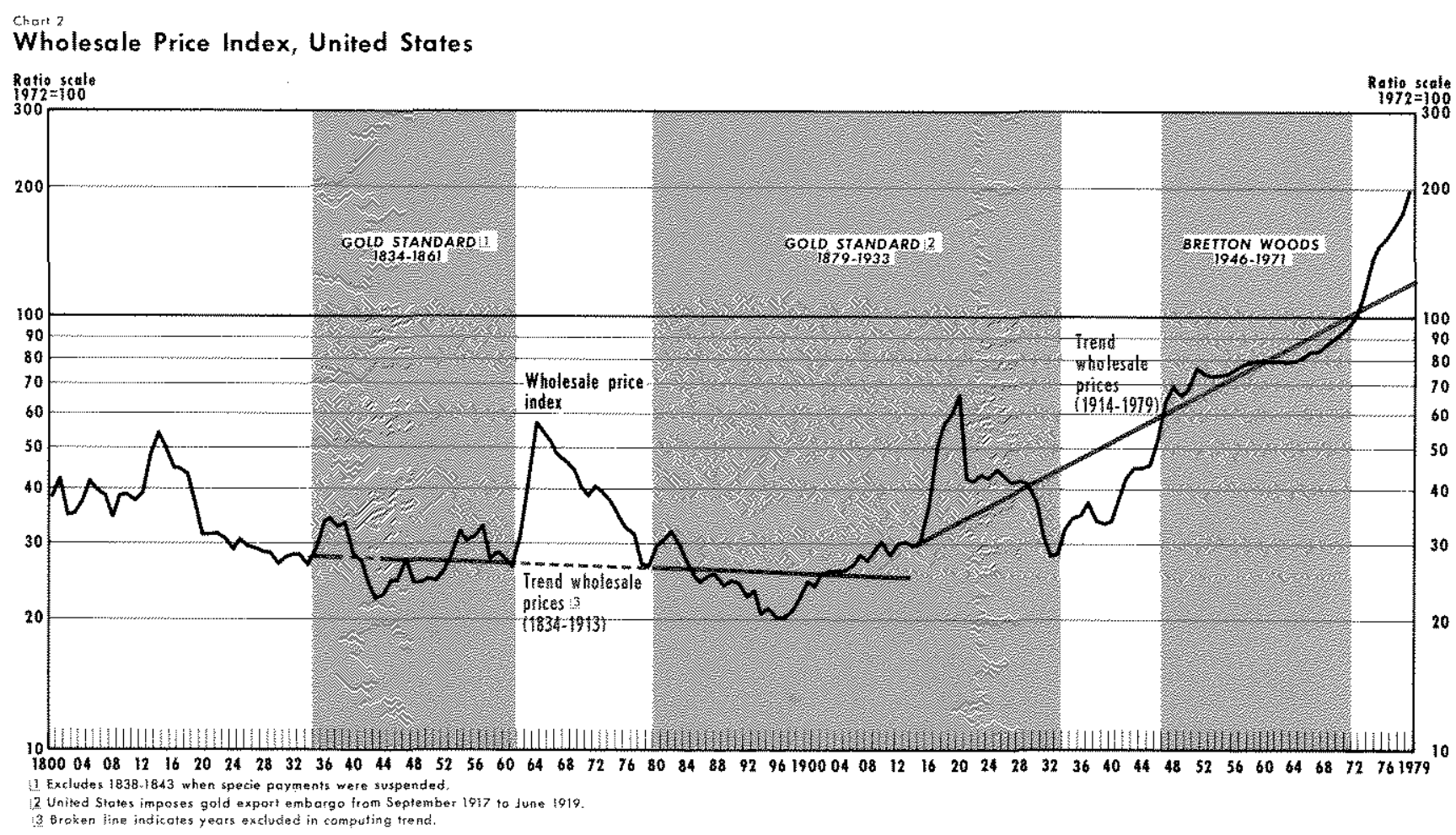

terized by price stability except for the 1920 s under the Gold Exchange Standard, and the 1950s and early $1960 \mathrm{~s}$ under the Bretton Woods System. Indeed, since the end of the gold standard, price levels in both countries have on average been rising. The $U_{x} K$ price level increased at an average annual rate of 3.81 percent from 1914 to 1979 , while U.S. price level increased by an average annual rate of 2.2 percent.

Charts 3 and 4 present further evidence on the operation of a commodity money standard and on the long-run price stabilizing character of the gold standard.

Chart 3 compares the purchasing power of gold for the world (measured by the ratio of an index of the price of gold to the wholesale price index for the United Kingdom) in relation to its trend with the world monetary gold stock in relation to its trend over the period 1821-1914. ${ }^{37}$

The purchasing power of gold index presented here varies inversely with the wholesale price index presented in chart 1 . This inverse association is a reflec-

37The United Kingdom was chosen to represent the pre-1914 world because it was a large open economy with few trade restrictions. Hence the wholesale price index would be domi. nated by internationally traded goods. tion of the fixed price of gold over this period. ${ }^{38}$ The trends of both series were rising over the whole period. The upward trend in the purchasing power of gold series reflects a more rapid growth of world real output and, hence, in the demand for monetary gold than could be accommodated by growth in the world's monetary gold stock.

In comparing deviations from trend in the purchasing power of gold to that in the world monetary gold stock, one would expect that deviations from trend in the monetary gold stock would produce corresponding changes in the price level and, for a given nominal price of gold, would inversely affect the purchasing power of gold. A comparison reveals this negative association, with deviations from trend in the world monetary gold stock leading deviations from trend in the purchasing power of gold. ${ }^{39}$

38 Indeed this inverse relationship prevailed virtually until the late 1960s. Since the freeing of the price of gold in 1968, the purchasing power af gold has varied directly with the wholesale price index. This primarily reflects rising demand for gold as a hedge against inflation, and increasing world political and monetary instability.

39The highest statistically significant negative correlation in the 1821-1914 period occurred with deviations from trend in the monetary gold stock leading deviations from trend in the purchasing power of gold by two years. The correlation coefficient, -644 , was statistically significant at the 1 percent level. 


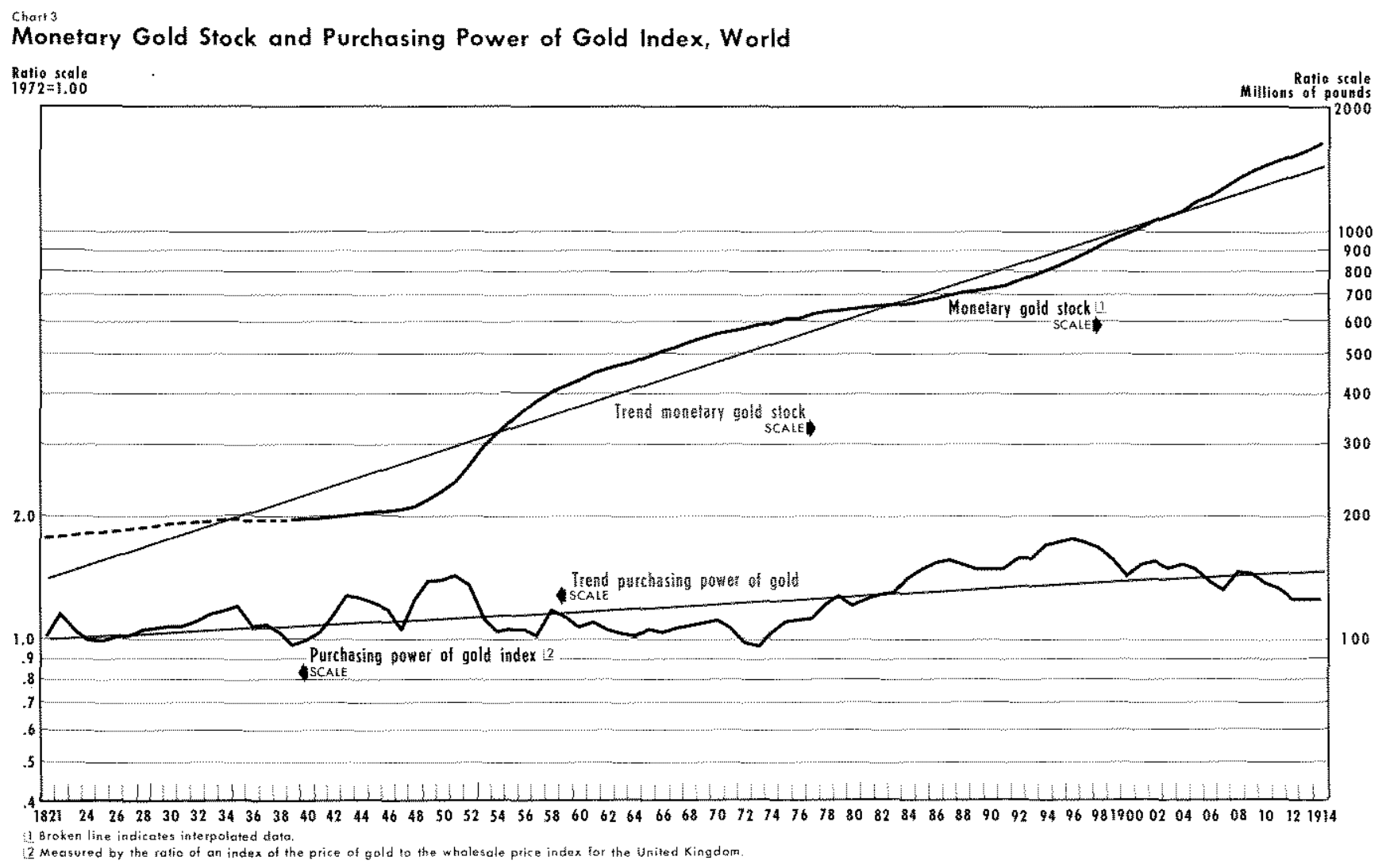

In addition, according to the operation of a commodity money standard, movements in the purchasing power of gold would be expected to precede movements in the monetary gold stock - a rising purchasing power of gold would induce both a shift from nonmonetary to monetary uses of gold and increased gold production. Such a positive association between deviations from trend of the two series is observed.40 Thus the $1820 \mathrm{~s}$ and "30s were largely characterized by the purchasing power of gold exceeding its long-run trend. This was followed by a rapid increase in the world monetary gold stock after 1848 as the output of the new California and Australian mines were added to the world's stock. Subsequently, the purchasing power of gold declined from its peak above trend in the mid-1850s and was succeeded by a marked deceleration in the monetary gold stock after 1860 . The same pattern can be observed comparing the rise in the purchasing power of

40The highest statistically significant positive correlation in the 1821-1914 period accurred with deviations from trend in the purchasing power of gold leading deviations from trend in the world monetary gold stock by 25 years. The correlation was 436 , statistically significant at the 1 percent level. gold in the 1870 s and ' 80 s with the subsequent in crease in the monetary gold stock in the mid-1890s.

Chart 4 compares the U.S. purchasing power of gold in relation to its trend with the U.S. monetary gold stock in relation to its trend over the 1879-1914 gold standard period, ${ }^{41}$

In this period, the trends of the two series moved in opposite directions. The declining trend in the purchasing power of gold series, reflecting more rapid growth in the U.S. monetary gold stock than in real output, was a consequence of two developments: the accumulation of monetary gold from the rest of the world early in the period following the resumption of specie payments, and the effects of gold discoveries in the 1890s.

As in chart 3 , a negative association between deviations from trend in the monetary gold stock and

\footnotetext{
41 An important difference in comparing the behavior of the U.S. ronetary gold stock with that of the world is that short-nun movements in the U.S. series would reflect, in addition to changes in gold production and shifts between monetary and nonmonetary uses of gold, gold movements between the United States and other comtries.
} 


\section{Monetary Gold Stock and Purchasing Power of Gold Index, United States}

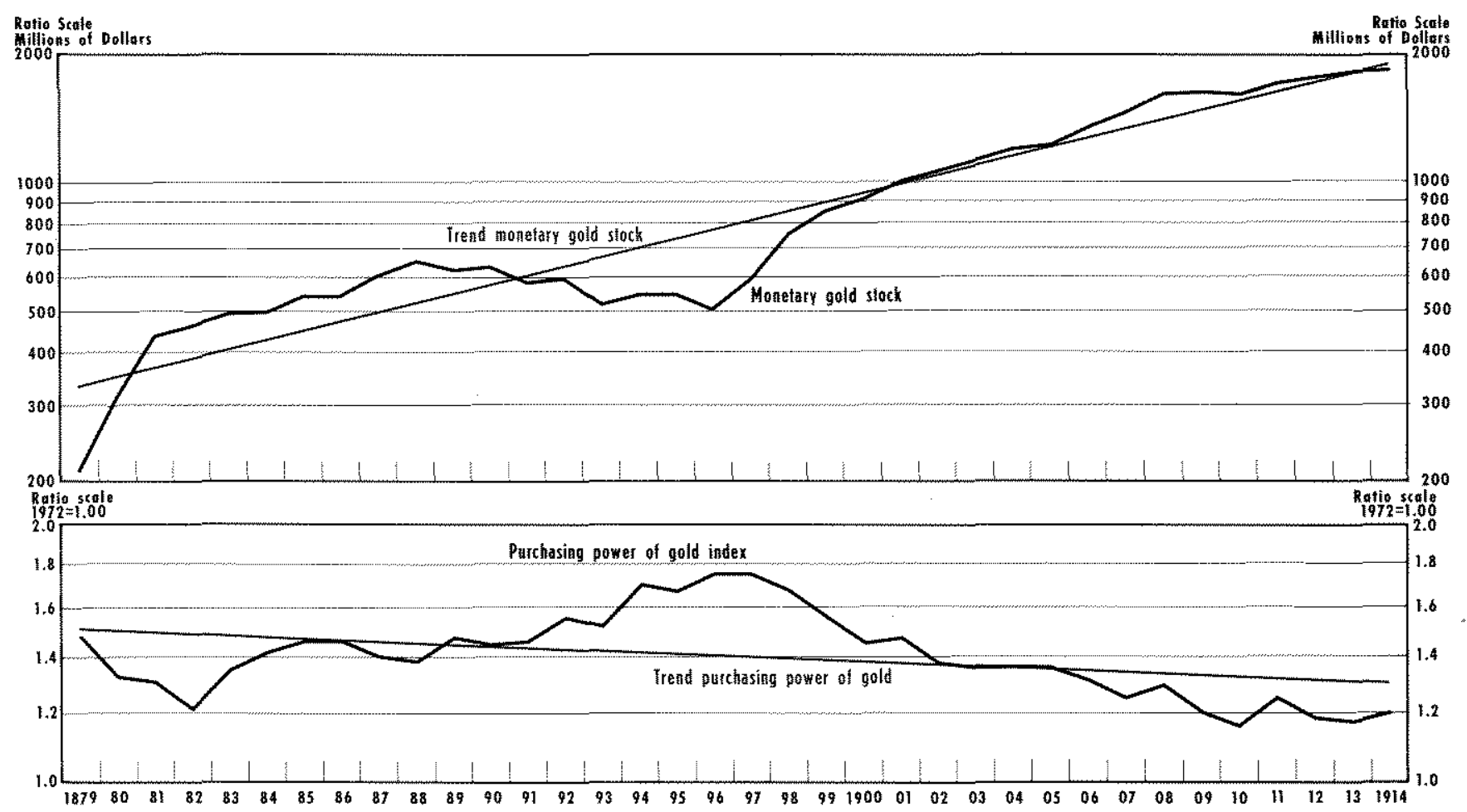

the purchasing power of gold is observed.42 Also, similar to the evidence in chart 3 , deviations in trend in the purchasing power of gold preceded deviations from trend in the monetary gold stock with a lead. ${ }^{43}$ Thus, declines in the purchasing power of gold from 1879 to 1882 preceded declines in the monetary gold stock below trend in the late 1880 s and early 1890 s, while rises in the purchasing power of gold after 1882 can be associated with a rising monetary gold stock after 1896. Finally, a declining purchasing power of gold in the mid-1890s can be associated with a falling monetary gold stock after 1903.

42The highest statistically significant negative correlation in the 1879-1914 period occurred with a contemporaneous relationship between deviations from trend in the monetary gold stock and deviations from trend in the purchasing power of gold. The correlation coefficient, -.656 , was statistically significant at the 1 percent level.

43The highest statistically significant positive correlation in the 1879-1914 period occurred with deviations from trend in the purchasing power of gold leading deviations from trend in the monetary gold stock by 14 years. The correlation coefficient was 793 , which was statistically significant at the I percent level.

The highest statistically significant positive correlation in the 1879 -1914 period occurred with deviations from trend in the world purchasing power of gold leading deviations from trend in the world monetary gold stock by 16 years. The correlation coefficient was .863 , which was statistically
One important implication of the tendency for price levels to revert toward a long-run stable value under the gold standard was that it insured a measure of predictability with respect to the value of money: though prices would rise or fall for a few years, inflam tion or deflation would not persist. ${ }^{44}$ Such belief in long-run price stability would encourage economic agents to engage in contracts with the expectation

significant at the 1 percent level. The considerably longer lead observed over the 1821-1914 period in footnote 40 above likely reflects a longer adjustment period in the early part of the 19 th century.

4 See Benjamin Klein, "Our New Monetary Standard: The Measurement and Effects of Price Uncertainty, 1880-1973," Economic Inquiry (December 1975), pp. 461-84 for evidence of long-run price stability for the United States under the gold standard. His evidence that positive (negative) autocorrelations of the price level are succeeded by negative (positive) autocorrelations is consistent with the hypothesis that the price level reverted back to its mean level. A consequence of this mean reversion phenomenon was that yearto-year changes in the price level were substantial for each country. However, the standard deviations of year-to-year changes in the wholesale price index were still considerably lower in the pre-World War 1 gold standard era compared with the post-World War I managed fiduciary money era. For the United Kingdom, the standard deviations were: $1821-1913$, $6.20 ; 1919-79$ (excluding 1939-45), 12.00. For the United States, the standard deviations were: $1834-1913$ (excluding $1838-43$ and $1861-78$ ), 6.29; $1919-79$ (excluding 1941-45), 9.28 . 


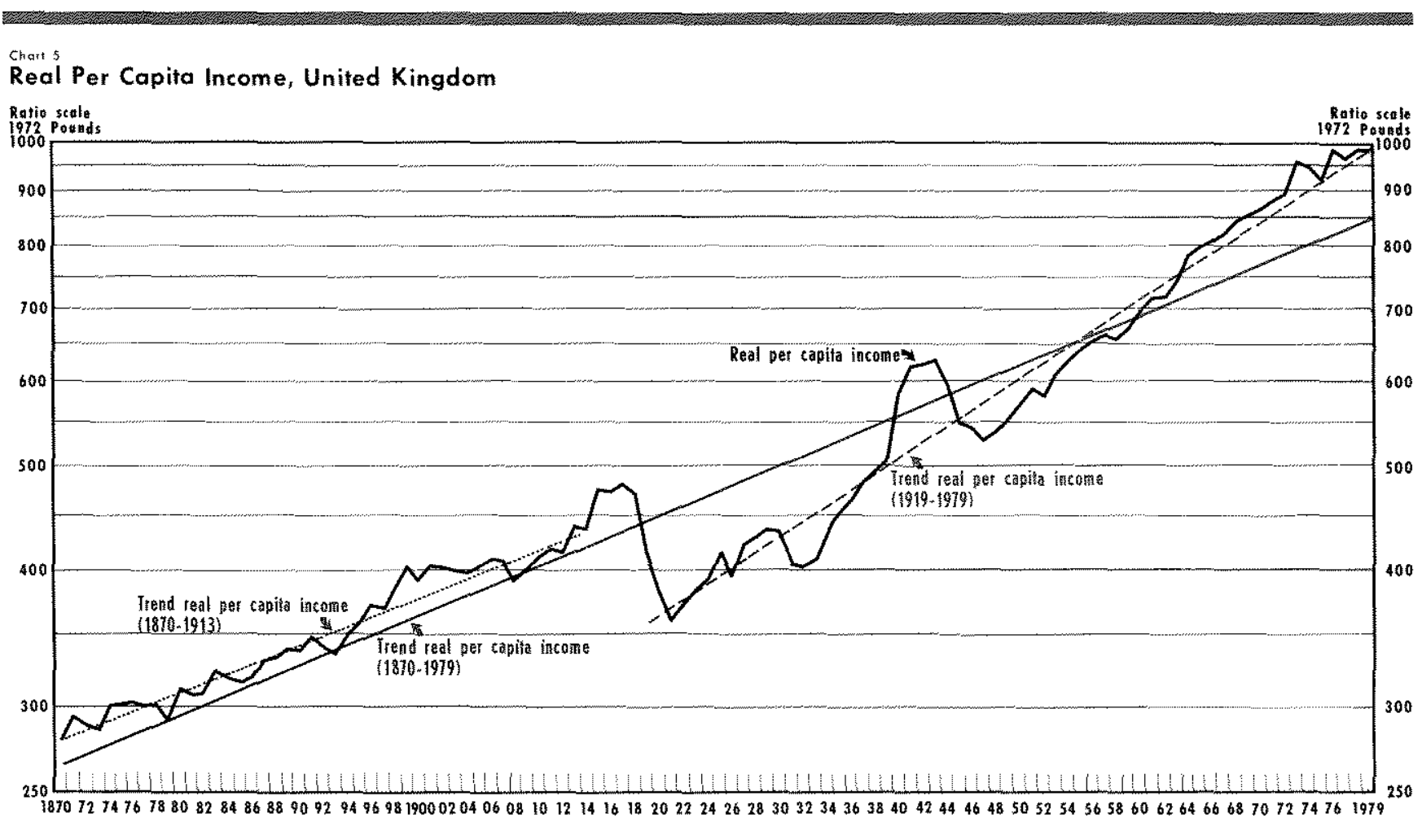

that, should prices of commodities or factors of production change, the change would reflect real forces rather than changes in the value of money.

Belief in long-term price level stability has apparently disappeared in recent years, as people now realize that the long-run constraint of the gold standard has vanished. ${ }^{4 \bar{a}}$ As a consequence, it is more difficult for people to distinguish between changes in relative prices and changes in the price level. Such absolute vs. relative price confusion has increased the possibility of major economic losses as people fail to respond to market signals. ${ }^{46}$

Finally, evidence on real output stability for the United Kingdom and the United States is presented. It is frequently argued that under the gold standard,

45Indeed, evidence presented by Klein, "Our New Monetary Standard," shows a marked dectine since 1960 in long-term price level predictability, the belief about long-term price behavior (measured by a moving standard deviation of changes in the price level). At the same time, short-term price level predictability, the belief about price level behavior in the near future, has improved in the post-war period.

46 See Friedrich August von Hayek, A Tiger by the Tail, Hobart Papers (Institute of Economic Affairs, 1972); Milton Fried. man, "Nobel Lecture: Inflation and Unemployment," Journal of Political Economy (Iune 1977), pp. 451-72; and Axel Leijonhuvud, "Costs and Consequences of Inflation," in Axel Leijonhurvad, Information and Comordination: Essays in Macro Economic Theory (Oxford University Press, 1981). when countries had to subordinate internal balance considerations to the gold standard's iron discipline, real output would be less stable than under a regime of managed fiduciary money. Charts 5 and 6 show the deviations of real per capita income from its longrun trend over the period 1870 to 1979 .

For the United Kingdom, chart 5 shows both a single trend line for the 1870-1979 period and separate trend lines for each of the pre- and postWorld War I subperiods. The U.K. data was split into two subperiods because the trend line for the entire period results in real output after 1919 being virtually always below trend. This suggests that World War I permanently altered the trend growth rate of real per capita income in the United Kingdom and, hence, the two periods should be handled separately. Examining the deviations from trend (using the subperiod trends) suggests that real per capita income was less variable in the pre-World War I period than subsequently. The mean absolute value of the percentage deviations of real per capita income from trend was 2.14 percent from $1870-1913$ and 3.75 percent from 1919-79 (excluding 1939-45).

As in the U.K. case, U.S. real per capita income was more stable under the gold standard from 1879 to 1913 compared with the entire post-World War I 
Rea

Real Per Capita Income, United States

Ratio seate
1972 Dollers

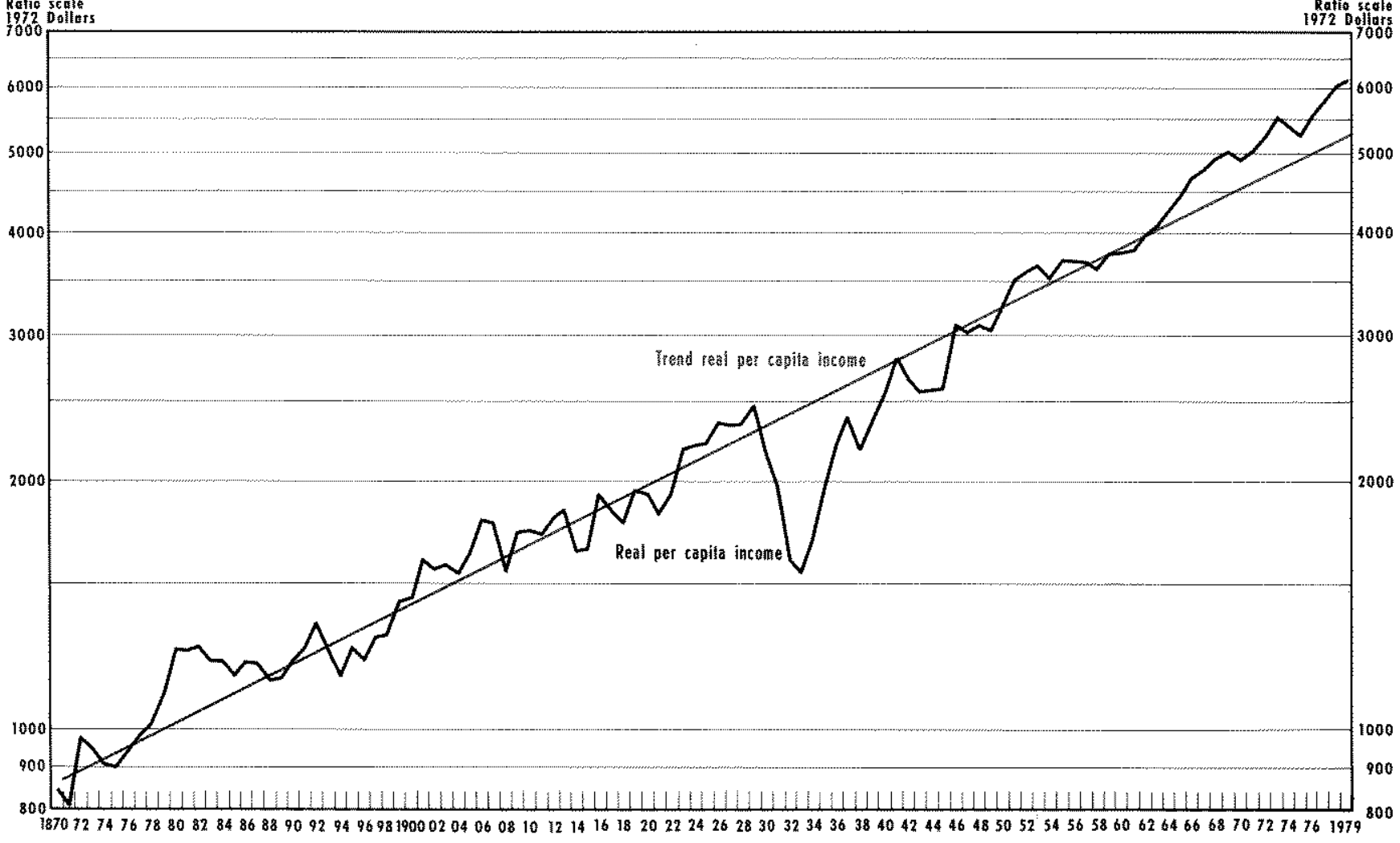

period. The mean absolute values of the percentage deviations of real per capita income from trend were: 6.64 percent from $1879-1913$ and 8.97 percent from 1919-79 (excluding 1941-45).

Moreover, unemployment was on average lower in the pre-1914 period in both countries than in the postWorld War I period. For the United Kingdom, the average unemployment rate over the $1888-1913$ period was 4.30 percent, while over the period 1919 79 (excluding 1939-45) it was 6.52 percent. For the United States, average unemployment rates by subperiod were: 1890-1913, 6.78 percent and 1919-79 (excluding 1941-45), 7.46 percent.

Thus, the evidence suggests that the managed fiduciary money system superceding the gold standard generally has been associated with less real economic stability.

\section{THE CASE FOR A RETURN TO GOLD}

The pre-World War I gold standard was the closest thing to a worldwide commodity money standard. Hence, an examination of the record for that period is crucial in determining what we might expect should we return to some form of commodity standard.

One dominant feature of that period was long-run price stability. This contrasts favorably with the behavior of the price level under the managed fiduciary money standard for much of the period since World War 1. Also, though real output varied considerably from year to year under the gold standard, it did not vary discernibly more than it has in the entire period since the first world war. ${ }^{47}$

One problem with comparing the pre-World War I gold standard to the managed fiduciary money standard after World War I is that the latter period includes the turbulent interwar years, a period that may bias the case against managed fiduciary money. To account for this, table 1 compares several measures of performance of the price level, real output and money growth for three time periods: the pre-World War I

47The standard deviations of year-to-year percentage changes in real per capita income for the United States were: 1879-1913 $5.79 ; 1919-79$ (excluding 1941-45), 6.34. For the United Kingdom: $1870-1913,2.62$; 1919-79 (excluding 1939-45), 
Table 1

\section{A Comparison of the Behavior of Price Level, Real Output and Money Growth in the United Kingdom and the United States}

\begin{tabular}{|c|c|c|c|c|c|c|c|}
\hline & & \multicolumn{2}{|c|}{ The Gold standard } & \multicolumn{2}{|c|}{ The Interwar Period } & \multicolumn{2}{|c|}{ Post World War II } \\
\hline & & UK & 0.5 & $\mathrm{UK}$ & Us & OK & $\mathrm{Us}$ \\
\hline & & $\begin{array}{l}1870-1913 \\
(1821-1913)\end{array}$ & $\begin{array}{l}1879-1913 \\
(1834-1913)\end{array}$ & 191938 & 191940 & 194679 & 194679 \\
\hline$(1)$ & $\begin{array}{l}\text { The average annual percentage } \\
\text { change in the price level }\end{array}$ & $+\frac{-0.7 \%}{0.4)}$ & $(-0.1)$ & $46 \%$ & $-25 \%$ & $6.6 \%$ & $28 \%$ \\
\hline (2) & $\begin{array}{l}\text { The coetficient of variation, } \\
\text { of annual percentage changes } \\
\text { In the price level (ratio) }\end{array}$ & $(-14.93)$ & $\begin{array}{l}170 \\
(6,5)\end{array}$ & -38 & 5.2 & 12 & 13 \\
\hline (3) & $\begin{array}{l}\text { The coefficient of variation } \\
\text { of annual percentage changes } \\
\text { In real per capita incomo } \\
\text { (ratio) }\end{array}$ & 26 & 3,6 & 49 & 6.6 & 14 & 16 \\
\hline (4) & $\begin{array}{l}\text { The average level of the } \\
\text { unemployment rate }\end{array}$ & $43 \%$ 2 & $6.8 \% 3$ & $13.3 \%$ & $11,3 \%$ & $25 \%$ & $60 \%$ \\
\hline (5) & $\begin{array}{l}\text { The average annual percentage } \\
\text { change in the money supply }\end{array}$ & $1,5 \%$ & $61 \%$ & $0.9 \%$ & $16 \%$ & $59 \%$ & $57 \%$ \\
\hline (6) & $\begin{array}{l}\text { The coefficient of variation of } \\
\text { annual percentage changes in } \\
\text { the noney supply (ratio) }\end{array}$ & 1.6 & 0.8 & 3,6 & 2.4 & 10 & 0,5 \\
\hline
\end{tabular}

Notes Rows 1 and 5 calculated as the time coefficient from a regression of the log of the vartable on a tine trend

rows 2,3 and 6 calctiated as the ratio of the standard deviation of arnual percentage changes to then mean.

TData for the longer peniods (in parentheses) were avallable only for the price level vears $1838-43$ and $1861-78$ were excluded for the United States.

$21888-1913$

$1890-1913$

Data Sources See data appendx

gold standard period, the interwar period and the post-World War II period. ${ }^{48}$

First, row 1 presents evidence on long-run price level stability as measured by the average annual rate of change in the price level over the period. As can be observed, the interwar period in both countries was characterized by substantial deflation in both the

\footnotetext{
48 In this comparison, both World Wars are onitted. This was done for two reasons. First, both wars were accompanied by rapid inflation in both countries, and in each case wartime government expenditures were largely financed by the issue of government fat money. Hence, a comparison of the pricestabilizing characteristics of the two monetary standards - ineluding two major wars in the case of the managed fiduciary money standard and none in the gold standard - wonld bias the case against the former. Second, measured real output would tend to be higher than otherwise in wartime to the extent that resources (both employed and otherwise unemployed) are devoted to (nonproductive) wartime use. Hence, including wartime real output wotld bias the case in favor of managed fiduciary money.
}

United States and the United Kingdom, while the post-World War II period has been characterized by inflation. This performance is in marked contrast to the near price stability of the gold standard period. However, price variability, measured in row 2 by the coefficient of variation of percentage year-to-year changes in the price level, reveals a slightly different picture. Prices were more variable under the gold standard than in both post-gold-standard periods, with the least variability occurring in the post-World War II period.

Second, row 3 presents evidence on real output stability as measured by the coefficient of variation of year-to-year percentage changes in real per capita output. Real output was considerably less stable in both countries in the interwar period than in either the gold standard or the post-World War II period, 
with the latter period having the best record. In addition, the evidence on average unemployment rates in row 4 agrees with the evidence on real output stability: unemployment was by far the highest in the interwar period and by far the lowest in the postWorld War II period in both countries. ${ }^{49}$

Finally, a comparison is made across periods in the average annual rate of monetary growth in row 5 , and in the variability in monetary growth measured by the coefficient of variation of percentage year-to-year changes in the money supply in row 6 . According to monetary theory, a reduction in monetary growth below the long-run trend of real output growth will produce deflation, while a rise in monetary growth above the long-run trend of real output growth will lead to inflation. In the transition between different rates of monetary growth, both the levels and growth rates of real output will deviate considerably from long-run trend. Thus monetary variability will lead to real output variability. ${ }^{50}$

The rate of monetary growth was lower in both countries in the interwar period than in both the postWorld War II and the gold standard periods. In the case of the United Kingdom, the post-World War II period exhibits more rapid monetary growth than under the gold standard, while for the United States, monetary growth rates are similar in both the postwar and gold standard periods.

Finally, monetary growth was more variable in both countries in the interwar period than in the other two periods, with the post-World War II period displaying the least variability in monetary growth.

The poor economic performance of the interwar period compared with either the preceding gold standard period or the post-World War II period has been attributed to the failure of monetary policy. Indeed, the attempt by the Bank of England to restore convertibility to gold at the pre-war parity has often been characterized as the reason for British deflation

\footnotetext{
$49 \mathrm{~A}$ comparison between the two unemployment rates and the measures of real output stability reveals an interesting difference. Real output was less stable in the United States, but unemployment was higher in the United Kingdom. One explarkation offered for the high and persistent inemployment in the United Kingdom in the interwar period is that it was caused by significant increases in the ratio of unemployment benefits to wages, See Daniel $K$. Benjamin and Levis $A$. Kochin, "Searching for an Explanation of Unemployment in Interwar Britain," Journal of Political Economy (June 1979), pp. $441-78$.

onsee Milton Friedman, A Theoretical Framework for Monetary Analysis, Occasional Paper No. 112 (National Buteat of Economic Research, 1971 ).
}

and unemployment in the 1920s. ${ }^{51}$ Likewise, the failure of the Federal Reserve System to prevent the drastic decline which occurred in the U.S. money supply from 1929 to 1933 has been blamed for the severity of the Great Depression in the United States ${ }^{52}$ One could well argue that the greatly improved performance of monetary policy and economic stability in the two countries in the post-World War II period reflects learning from past mistakes. This suggests that in considering the case for a return to the gold standard, a meaningful comparison should really be made between the post-World War II period and the gold standard. In such a comparison, the gold standard provided us with greater long-run price stability, but at the expense of both short-run real output and price stability. The higher rates of inflation and lower variability of real output (and lower unemployment) in the two countries in the recent period likely reflects changing policy preferences away from long-run price stability and toward full employment. Indeed, the strong commitment to full employment in both countries likely explains the worsening of inflation in the post-war period. ${ }^{\text {s3 }}$

In assessing the case for a U.S. return to a gold standard, the benefits of such a policy must be weighed against the costs. The key benefit of a return to a gold standard would be long-run price stability. The costs, however, are not inconsiderable. A commodity money standard such as the gold standard involves significant economic costs: (1) the resource costs of maintaining the standard and (2) the shortrun instability of both the price level and real output that would accompany the adjustment of the commodity to changing supply and demand conditions.

Moreover, the history of the pre-World War I gold standard suggests that it worked because it was a "managed" international standard. In addition, the concentration of world capital and money markets in London and the use of sterling as a key currency enabled the system to function smoothly with limited gold reserves and to withstand a number of severe external shocks. Perhaps of paramount importance for the successful operation of the managed gold standard

\footnotetext{
51See John Maynard Keynes, "The Economic Consequences of Mr. Churchill," in Johnson and Moggridge, eds., Collected Works of John Maynard Keynes, vol. IX (1972).

${ }^{2}$ See Friedman and Schwartz, A Monetary History of the United States.

53 Friedman forcefully argued this point in his 1968 presidential address to the Anerican Economic Association. See Milton Friedman, "The Role of Monetary Policy," The American Economic Review (March 1968), pp. 1-17.
} 
was the tacit cooperation of the major participants in (ultimately) maintaining the gold standard link and its corollary, long-run price stability, as the primary goal of economic policy. ${ }^{5}$. This suggests that one country alone on the gold standard would likely find its monetary gold stock and hence its money supply

${ }^{5} 4$ Other conditions amenable to the successful operation of the gold standard were the free mobility of labor and capitat, the ahsence of exchange controls and the absence of any niajor wars

\section{Data Appendix}

\section{Chart 1}

\section{United Kingdom}

1. Wholesale Prices 1800-1979. (1972 = 100). Data for 1800-1938 and 1946-1975 from Roy W. Jastram, The Golden Constant (John Wiley and Sons, New York, 1977), Table 2, pp. 32-33; 1939-1945 from B. R. Mitchell, European Historical Statistics 1750-1970 (Columbia University Press, New York, 1975), Table I1, p. 739; 1976-78 Central Statistical Office, Economic Trends Annual Supplement 1980 Edition (Her Majes. ty's Stationery Office, London, 1979), p. 112, series: Wholesale Prices for All Manufactured Products, 1976 figure used was an average of the CSO 1976 value and Jastram's 1976 value; 1979 from CSO, Monthly Digest of Statistics (Her Majesty's Stationery Office, London, Nov. 1980 ), p. 159 , series: same as $1976-78$.

\section{Chart 2}

\section{United States}

1. Wholesale Prices $1800-1979 .(1972=100)$. Data for 1800-1975 from Roy W. Jastram, The Golden Constant (John Wiley and Sons, New York, 1977), Table 7 , pp. 145-46, 1976 from U.S. Dept of Labor, Bureau of Labor Statistics, Wholesale Prices and Indexes Supplement 1977 (1977), Table 4, series: All Commodities; 1977 from Dept. of Labor, BLS, Monthly Labor Review (April 1978), Table 26, series: All Commodities; 1978 from Monthly Labor Review (April 1979), Table 27, series; All Commodities; 1979 from Dept. of Labor, BLS, Supplement to Producer Prices and Price Indexes Data for 1979 (1980), Table 4, series: All Commodities. subject to persistent shocks from factors beyond its control.

A fiduciary money standard based on a monetary rule of a steady and known rate of monetary growth could provide both greater price level and real output stability than a return to the gold standard. The key problem with a fiduciary system, however, is to ensure that such a rule is maintained and that a commitment be made to the goal of long-run price stability.

\section{Chart 3}

World

1. United Kingdom Purchasing Power of Gold 1821-1914. $(1972=1.00)$. 1821-1914 from Roy W. Jastram, The Golden Constant (John Wiley and Sons, New York, 1977), Table 3, pp. 36-37.

2. World Monetary Gold Stock 1821-1914. Data for 182138 represent interpolation between values for 1807 , 1833 and 1839. These values, along with the 18391914 values, from League of Nations, Interim Report of the Gold Delegation and Report of the Gold Delegation (Amo Press, New York, 1978), Table B, col. (1), series: Monetary Stock of Gold, end of year,

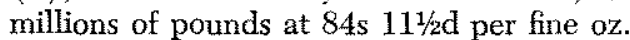

\section{Chart 4}

\section{United States}

1. Purchasing Power of Gold 1879-1914. (1972 1.00 ). Data for 1879-1914 from Roy W. Jastram, The Golden Constant (John Wiley and Sons, New York, 1977), Table 8, pp. $147-48$.

2. Monetary Gold Stock 1879-1914. Data for 1879-1914 from Phillip Cagan, Determinants and Effects of Changes in the Stock of Money 1875-1960 (Columbia University Press, New York, 1965), Appendix F, Table F-7, col. (1), current par value $=\$ 20.67$ per oz. Cagan's sources include the following: 1879-1907, Annual Report, Mint, 1907; 1908-1913, Circulation Statement of United States Money; 1914, Banking and Monetary Statistics, FRB, 1941. 


\section{Chart 5}

\section{United Kingdom}

1. Real Per Capita Income 1870-1979. (1972 pounds).

(a) Nominal Income 1870-1979. Data for 1870-1975 from Milton Friedman and Anna J. Schwartz, forthcoming Monetary Trends in the United States and the United Kingdom: Their Relation to Income, Prices, and Interest Rates 1867-1975, National Bureau of Economic Research, Chapter 4, Table 4-A-2, col. (2). Nominal income for 1976 79 computed as GNP at factor cost less consumption of fixed capital. 1976-78 GNP at factor cost from CSO, Economic Trends Annual Supplement 1980 Edition, Table 36, col. (2); 1979 GND at factor cost from CSO, Monthly Digest of Statistics (Jan. 1981), Table 1.2, col. (2). 1976-79 Constumption of fixed capital from OECD, National Accounts of OECD Countries (Paris, 1981), Vol. 1 , p. 70, series \#36: Consumption of the Fixed Capital.

(b) Implicit Price Deflator 1870-1979. (1972=100). Data for 1870-1975 from Friedman and Schwartz, Monetary Trends, Chapter 4, Table 4-A-2, col. (4); 1976-79 from International Monetary Fund, Intemational Financial Statistics (Jan. 1981), p. 404; delator calculated as $\mathrm{P}=100 \times$ (nominal GDP/real GDP), real and nominal GDP appearing in $I F S$.

(c) Population 1870-1979. Data for $1870-1965$ from C. Feinstein, National Income, Expenditure and Output of the United Kingdom, 1855-1965, Table 44, col. (1); 1966-75 from CSO, Annual Statistical Abstract; $1976-79$ from CSO, Monthly Digest of Statistics (Nov, 1980), p. 16.

\section{Chart 6}

\section{United States}

1. Real Per Capita Income 1870-1979. (1972 dollars). This series is the result of splicing together two series, the earlier based upon data from Friedman and Schwartz, Monetary Trends and the later based upon data from U.S. Dept, of Commerce, Survey of Current Business.

For 1870-1949, a real per capita income series was computed using the following data: nominal income, Friedman and Schwartz, Monetary Trends, Chapter 4, Table 4-A-1, col. (2); implicit price deflator, $1972=$ 100, Chapter 4, Table 4-A-1, col. (1); population, U.S. Department of Commerce, Historical Statistics
(1960). This series was then adjusted in the following way:

$[\mathrm{Y} /(\mathrm{P} \times \mathrm{N})]_{\mathrm{t}}=\exp \left[\ln \left(\mathrm{FS}_{t}\right)+\left(\ln \left(\mathrm{SCB}_{1950}\right)-\right.\right.$

In $\left.\left.\left(F S_{1950}\right)\right)\right], t=1870, \ldots, 1949$

where $\mathrm{FS}_{\mathrm{t}}=$ Friedman-Schwartz value of real per capita income in time $t$ and $\mathrm{SCB}_{\mathrm{t}}=$ Survey of Current Business value in time $t$. The adjusted series was then joined to the $1950-1979$ series computed from the following data in the Survey of Current Business: nominal NNP, average of quarterly figures, seasonally adjusted and NNP implicit price deflator, average of quarterly figures, $1972=100$; population data (resident population less ammed forces, average of monthly figures) from U.S. Dept. of Commerce, Bureau of the Census.

\section{Other Data Used}

1. U.S. Unemployment Rates 1890-1979. Data for 18901900 from Stanley Lebergott, "Changes in Unemployment 1800-1960", in Robert W. Fogel and Stanley L. Engerman, eds., The Reinterpretation of American Economic History (Harper \& Row, New York, 1971), p. 80, Table 1; 1901-57 from Dept. of Commerce, Bureau of the Census, Historical Statistics of the United States (1960), series D-47; 1958 from Dept. of Labor; BLS, Monthly Labor Review Statistical Supplement (1959), Table I-1; 1959-62 from MLR Statistical Supplement (1962), Table I-1, p. 1; 1963 from MLR Statistical Supplement (1963), Table I-1; 1964-79 from Dept. of Labor, BLS, Monthly Labor Review (Jan. 1981), Table 1.

2. Great Britain Unemployment Rates 1888-1979. Data for 1888-1966 from B. R. Mitchell, European Historical Statistics 1750-1970 (Columbia University Press, 1975), Table C2, series: UK:CB; $1967-72$ from CSO, Monthly Digest of Statistics (March 1973), Table 21, series: Percent unemployed of total employees for Great Britain; 1973-77 from same publication as for $1967-72$ (Oct. 1978), Table 3.9, series: same as that for $1967-72$; $1978-1979$ from same publication as 1967-72 (Nov. 1980), Table 3.10, series: same as that for $1967-72$.

3. U.S. Money Supply 1879-1979. Data for 1879-1975 from Friedman and Schwartz, Monetary Trends, Chapter 4, Table 4-A-1, col. (1); 1976-1979 from Board of Governors of the Federal Reserve System, Statistical Release: Money Stock Measures, H.6, series M2, annual average of monthy figures, seasonally adjusted.

4. U.K. Money Supply 1870-1979. Data for 1870-1975 from Friedman and Schwartz, Monetary Trends, Chapter 4, Table 4-A-2, col. (1); 1976-79 trom CSO, Financial Statistics (Her Majesty's Stationery Office, London, Nov. 1980), p. 144, series: M3, not seasonally adjusted, end of second quarter. 